\title{
PRIVATE CAPITAL FLOWS TO LOW-INCOME COUNTRIES: THE ROLE OF DOMESTIC FINANCIAL SECTOR
}

\author{
Chee-Keong Choong ${ }^{1}$, Siew-Yong Lam ${ }^{2}$, Zulkornain Yusop ${ }^{3}$ \\ ${ }^{1}$ Centre for Economic Studies, Faculty of Business and Finance, \\ Universiti Tunku Abdul Rahman (Perak Campus), Jalan Universiti, Bandar Barat, \\ 31900 Kampar, Perak Darul Ridzuan, Malaysia \\ ${ }^{2}$ Centre for Business and Management, Faculty of Business and Finance, \\ Universiti Tunku Abdul Rahman (Perak Campus), Jalan Universiti, Bandar Barat, \\ 31900 Kampar, Perak Darul Ridzuan, Malaysia \\ ${ }^{3}$ Department of Economics, Faculty of Economics and Management, \\ Universiti Putra Malaysia, 43400 Serdang, Selangor Darul Ehsan, Malaysia \\ E-mails: ${ }^{1}$ choongck@utar.edu.my (corresponding author); ${ }^{2}$ lamsy@utar.edu.my; \\ ${ }^{3}$ zulyusop@econ.upm.edu.my
}

Received 9 December 2009; accepted 17 September 2010

\begin{abstract}
The relationship between private capital flows and growth has been examined extensively in the literature, yet numerous controversies still remain. The study examines the relationships among private capital flows (foreign direct investment, portfolio investment and foreign debt), financial development and economic performance in a sample of 16 low-income developing countries over the period 1988-2006, by employing generalized method of moments (GMM) panel data analysis. We find that private capital flows have a positive impact on growth in low-income countries with well-developed financial sector but have a negative effect in the presence of poor financial sector development. Well-developed financial sectors are ones that are themselves crucial for economic growth. Our results indicate that private capital flows would be more effective if they were more systematically conditional on well-developed financial systems.
\end{abstract}

Keywords: private capital flows, stock market, growth, panel data analysis.

Reference to this paper should be made as follows: Choong, C.-K.; Lam, S.-Y.; Yusop, Z. 2010. Private Capital Flows to Low-Income Countries: The Role of Domestic Financial Sector, Journal of Business Economics and Management 11(4): 598-612.

\section{Introduction}

In recent years, there has been a revival of interest on the nature and role of private capital flows and their impact on investment and economic growth of host countries (Andersen and Tarp 2003; Albuquerque 2003; Soto 2003; Mody and Murshid 2005; Giovanni 2005; Khamfula 2007; Pazienza and Vecchione 2009; Tvaronavičienė et al. 2008; Tvaronavičienė and Kalašinskaite 2010; Weng et al. 2010). In developing countries, this interest has been fueled by the reappearance of huge private capital inflows 
since the early 1990s, through a process of rapid financial sector liberalization (Blejer 2006; Bordo and Meissner 2006; Eller et al. 2006).

The findings of the research between private capital flows and economic growth, however, have been mixed. On the one hand, some studies conclude that private capital inflows raise the efficiency of recipient country such as stimulating capital accumulation (de Mello 1996, 1997; Adams 2009), improving resource allocation (Reisen and Soto 2001), interacting with human capital (Borensztein et al. 1998; Wang and Wong 2009), promoting international trade (Balasubramanyam et al. 1996; Basu and Guariglia 2007; Liu et al. 2009) and deepening domestic financial sector (Hermes and Lensink 2003; Alfaro et al. 2004; Durham 2004; Azman-Saini et al. 2010). On the other hand, counterevidence also exists and argues that: "There is a growing agreement that excessive build-up of short-term debt was a proximate cause of the recent crises..." (Rodrik and Velasco 1999); “... short-term capital inflows can be counterproductive as they may hinder economic growth through externalities emanated both during the surges and sudden reversals" (Baharumshah and Thanoon 2006: 81); and "... private capital flows do not help but do not hurt either economic growth in developing countries" (Soto 2003: 218). In short, the effects of private capital flows on economic growth still remain ambiguous.

Bearing this in mind, therefore, the study aims to investigate the role of domestic financial sector in examining the linkages between private capital flows (foreign direct investment (FDI), portfolio investment and foreign debt) and economic growth in the selected low-income countries from 1988 to 2006, using generalized method of moments (GMM) panel data model. A number of studies point out the importance of domestic financial system in attracting the private capital flows (Reisen and Soto 2001; Hermes and Lensink 2003; Alfaro et al. 2004; Dumludag 2009). For example, Reisen and Soto (2001: 12-13) concluded that "Foreign saving ... has been shown to contribute to growth only if the banking system is well-capitalised; otherwise "good" risks will be underfinanced and "bad" risks overfinanced"1. Moreover, the extent of direct participation in local exchanges and gains due to the presence of private capital flows (financial liberalization) depends on market investability manifested by financial market breadth, depth, liquidity, efficiency, regulation, information, removal of perceived barriers (risks), transparency of investment and repatriation rules (Errunza 2001; Ucal et al. $2010)^{2}$. This would mean that a minimum level of financial development must be met before a country is in conformity to attract private capital flows in pursuit of enhancing its economic growth (Hermes and Lensink 2003; Alfaro et al. 2004; Durham 2004; Azman-Saini et al. 2010).

\footnotetext{
${ }^{1}$ A well-developed financial system provides fertile ground for the allocation of resources, better monitoring, better information symmetries, and economic growth (King and Levine 1993).

${ }^{2}$ Greater financial sector efficiency should result in an overall reduction of transaction costs. As a result, cost of borrowing (capital cost) might decline, as interest margins shrink. If these gains are being forwarded to the investors, the cost of borrowing in the markets will decline and promote investments and economic growth (Levine 1997).
} 
Growth of developing countries, especially low-income groups depends on a large extent on their own financial sector development ${ }^{3}$. Albuquerque (2003: 380) reveals: “... the relatively large proportion of FDI in private capital flows to less developed countries or low-income countries reflects their poor financial status rather than any comparative advantage". Therefore, we investigate a new about private capital flows: these capital flows do affect economic growth in the low-income countries; however, their impact is conditional on the development of domestic financial system.

While most studies on link between private capital flows, financial development and economic growth focus on the middle-income countries and high-income countries, there is a dearth of evidence on low-income countries as financial market and system in these countries are less developed. Questions remain regarding the relevance for researchers of previous literature that domestic financial system enhances the effect of private capital flows on growth in low-income countries. By focusing on this lowincome group, we could identify the role of financial development in influencing the link between private capital flows and growth. In other words, this study tends to find that financial systems may have a different impact on growth in earlier stages of development. It is believed that low-income countries with well-developed financial sector benefit directly more from private capital flows, and this environment accelerates the growth rate of economic.

The remainder of the paper is organized as follows: In Section 2, we present the panel data model used in this study. In Section 3, we discuss the impact of private capital flows on growth with and without interaction with financial sector development. The fourth section contains concluding remarks ad policy recommendations.

\section{Panel data regression models: generalized method of moments (GMM)}

The study uses recently developed dynamic panel generalized method of moments (GMM) techniques to examine the interactions among different sorts of private capital flows, financial development and economic growth in the 16 low-income countries in the period of 1988-2006 ${ }^{4}$. Following standard growth equation, we construct the following dynamic panel data model, as suggested by Arellano and Bond (1991):

$$
\begin{aligned}
& \Delta y_{i, t}=\alpha+\beta_{1} \Delta l_{i, t}+\beta_{2} \Delta k_{D i, t}+\beta_{3} \Delta k_{F i, t}+\beta_{4} \Delta f d_{i, t}+\beta_{5} \Delta X_{i, t}+ \\
& \beta_{6} \Delta f d^{*} \Delta k_{F i, t}+\tau_{t}+\eta_{i}+\varepsilon_{i, t},
\end{aligned}
$$

where $y_{i, t}$ be the logarithm of real GDP per capita growth rate in a country $i$ at time $t, l$ is the natural $\log$ of labour force; $k_{D}$ and $k_{F}$ represent the natural log of domestic capital stock and foreign capital flows respectively; $f d$ represents the natural log of

\footnotetext{
${ }^{3}$ In this regard, Levine (1997), Andersen and Tarp (2003), and Wachtel (2003) have provided comprehensive surveys on the relationship between financial development and economic growth.

${ }^{4}$ This method is fully described in Arellano and Bond (1991), Arellano and Bover (1995), and Blundell and Bond (1998).
} 
chosen financial development indicator; $X$ is a set of macroeconomic variables that are generally accepted to be important to explain economic growth; and $\varepsilon$ is a normally distributed error term.

Then Equation 1 can be simplified as follows:

$$
y_{i, t}-y_{i, t-1}=-\alpha y_{i, t-1}+\beta X_{i, t}+\tau_{t}+\eta_{i}+\varepsilon_{i, t},
$$

where $y_{i, t}-y_{i, t-1}\left(=\Delta y_{i, t}\right)$ is the growth rate in real per capital GDP; $\alpha$ is a parameter reflecting the convergence speed; $X_{i, t}$ is a set of explanatory variables, including a measure of financial development, labour, domestic capital stock, national saving, inflation, foreign capital flows and the interaction term, with associated parameter $\beta ; \eta_{i}$ captures unobserved country-specific effects; $\tau_{t}$ is a period-specific effect common to all countries; and $\varepsilon_{i t}$ is disturbance term.

According to Arellano and Bond (1991), there is a strong autoregressive structure in the residual term. This is not a surprise because the model is using annual data and business-cycle effects may propagate for more than one year. In order to deal with this problem, these business-cycle effects can be taken into account by assuming that $\mu_{i t}=\rho \mu_{i t-1}+\varepsilon_{i t}$, where $|\rho|<1$, and $\varepsilon_{i t}$ is white noise disturbance term. After rearranging terms, Equation 2 becomes:

$$
y_{i, t}=(1-\alpha+\rho) y_{i, t}-\rho(1-\alpha) y_{i, t-2}+X_{i, t} \beta-\rho X_{i, t-1} \beta+\tau_{t}-\rho \tau_{t-1}+(1-\rho) \eta_{i}+\varepsilon_{i, t} .
$$

First-differences are required in order to eliminate the country-specific effects.

From Equation 3, the lagged difference in per capita GDP is correlated with disturbance term, which may produce an endogeneity of the explanatory variables, $X$. Besides, Blundell and Bond (1998) argue that persistence in the explanatory variables may adversely affect the small-sample and asymptotic properties of the difference estimator, therefore, the difference estimator is further combined with an estimator in levels to produce a system estimator. In dealing with this econometric problem, it is required the use of instruments. Arellano and Bond (1991) have proposed few steps to overcome the problem. The first step is to eliminate the time effect, $\tau_{t}$ by subtracting from each variable by its cross average in period $t$. After that, the variables are transformed into first differences to eliminate the individual effect as follows:

$$
\Delta y_{i, t}=(1-\alpha+\rho) \Delta y_{i, t-1}+\rho(1-\alpha) \Delta y_{i, t-2}+\Delta X_{i, t} \beta+\rho \Delta X_{i, t-1} \beta+\Delta \varepsilon_{i, t} .
$$

Arellano and Bond (1991) essentially propose estimating Equation 4 with GMM using lagged levels of the endogenous variables as instruments. Nevertheless, the selection of instruments is important. The GMM difference estimator uses the lagged levels of the explanatory variables as instruments under the condition that the disturbance term is not serially correlated and that the levels of the explanatory variables are weakly exogenous - that is, they are uncorrelated with future error terms. If the condition that the explanatory variables are weakly exogenous is not hold, which is likely to be happen in the present context as the higher economic growth may promotes more capital inflows, 
both $X_{i t}$ and $X_{i t-1}$ are correlated with disturbance term in Equation 4. Therefore, only levels of variables lagged 2 years or more may be used as instruments.

Then, the following moment conditions are used to calculate the difference estimator:

$$
\begin{array}{ll}
E\left[y_{i, t-s}\left(\varepsilon_{i, t}-\varepsilon_{i, t-1}\right)\right]=0 \text { for } s \geq 2, & t=3, \ldots, T, \\
E\left[X_{i, t-s}\left(\varepsilon_{i, t}-\varepsilon_{i, t-1}\right)\right]=0 \text { for } s \geq 2, & t=3, \ldots, T .
\end{array}
$$

This is a necessary way in the estimation as the equation in levels uses the lagged differences of the explanatory variables as instruments under two conditions. First, the error term is not serially correlated. Second, although there may be correlation between the levels of the explanatory variables and the country-specific error term, there is no correlation between the difference in the explanatory variables and the error term. This yields the following stationarity properties:

$$
E\left[y_{i, t+p} \eta_{i}\right]=E\left[y_{i, t+q} \eta_{i}\right] \text { and } E\left[X_{i, t+p} \eta_{i}\right]=E\left[X_{i, t+q} \eta_{i}\right] \text { for all } p \text { and } q \text {. }
$$

The additional moment conditions for the regression in levels are:

$$
\begin{aligned}
& E\left[y_{i, t-s}-y_{i, t-s-1}\right)\left(\eta_{i}+\varepsilon_{i, t}\right)=0 \text { for } s=1, \\
& E\left[X_{i, t-s}-X_{i, t-s-1}\right)\left(\eta_{i}+\varepsilon_{i, t}\right)=0 \text { for } s=1 .
\end{aligned}
$$

In summary, the GMM system estimator is obtained using the moment conditions in Equations 5, 6, 8, and 9. Following Blundell and Bond (1998), the validity of the instruments used in these regressions is examined with two different statistics. The first is Sargan (or overidentifying restrictions) test aims to examine the null hypothesis that the instruments used are not correlated with the residuals. The second test is proposed by Arellano and Bond (1991), which examines the hypothesis that the residuals from the estimated regressions is first-order correlated but not second-order correlated ${ }^{5}$.

\section{Data sources}

Databases on the various categories of foreign capital flows to low-income countries from 1988 to 2006 are employed for the study. The sources of the variables used in this study are summarized in Table 1. The low-income countries chosen are based on the World Bank's income classification 2008. The selection of country and period were determined exclusively by data availability. This results in 16 low-income countries as shown in Table 2 to examine the relationship between private capital flows, financial development and economic growth.

\footnotetext{
${ }^{5}$ Arellano and Bond (1991) have called this test statistic as $\mathrm{m} 2$ test. For the test statistic, if the residuals $\varepsilon_{i t}$ were first-order correlated, then $y_{i, t-2}$ would be correlated with $\Delta \varepsilon_{\text {it }}$ and it could not be used as an instrument. The same is true with any variable from $X_{i t}$ that is temporarily correlated with $\varepsilon_{\mathrm{it}}$.
} 
Table 1. Data Sources

\begin{tabular}{ll}
\hline Variable & Data Source \\
\hline Real GDP per capita growth rate (GDPGR) & World Development Indicators, World Bank \\
\hline Capital stock (CAP) & World Development Indicators, World Bank \\
\hline Labour force (LF) & World Development Indicators, World Bank \\
\hline Saving as \% of GDP (NSAV) & World Development Indicators, World Bank \\
\hline Inflation (INF) & World Development Indicators, World Bank \\
\hline Foreign direct investment (FDI) & World Development Indicators, World Bank \\
\hline Portfolio investment (PI) & World Development Indicators, World Bank \\
\hline Foreign debt (DEBT) & World Development Indicators, World Bank \\
\hline Central Bank Assets to GDP ratio (CBAGDP) & Beck et al. (2000a) World Bank database \\
\hline $\begin{array}{l}\text { Deposit money bank assets to GDP ratio } \\
\text { (DBAGDP) }\end{array}$ & Beck et al. (2000a) World Bank database \\
\hline $\begin{array}{l}\text { Private credit by deposit money bank to GDP } \\
\text { ratio (PCGDP) }\end{array}$ & Beck et al. (2000a) World Bank database \\
\hline
\end{tabular}

Table 2. Low-income Countries based on the 2005 World Bank Income Classification

Bangladesh, Benin, Cameroon, Cote d’Ivoire, India, Kenya, Mauritania, Nicaragua, 16 Niger, Nigeria, Pakistan, Papua New Guinea, Rwanda, Senegal, Togo, Zimbabwe

\section{Results and interpretations}

\subsection{The relationship between private capital flows, financial development and economic growth}

Equations 1, 2 and 3 in Table 3 report the estimates of private capital flow and economic growth regressions for the low-income countries when the interaction term between private capital flows (FDI, portfolio and foreign debt) and financial development is not included, while Equations 4, 5 and 6 included the interaction term. Overall, the signs of the capital stock (CAP), labour force (LF) and national saving (NSAV) are positive and significant in most of the regressions. The findings are consistent with a priori, which shows that low-income countries have benefited from their national saving, capital stock and human capital development in promoting the economic growth rate.

On the other hand, the sign of the inflation rate is negative and statistically significant associated with GDP per capita growth rate in most regressions. Referring to the financial development indicator (CBAGDP), this variable is positively associated with economic growth in all regressions and it is statistically significant at 10 percent significance level or better. This implies that financial development is crucial to promote economic growth when the countries have well-developed banking and financial sector. 
Table 3. Private Capital Flows, Financial Development (CBAGDP) and Economic Growth in Low-Income Countries, 1988-2006

\begin{tabular}{|c|c|c|c|c|c|c|}
\hline Variable & Equ. 1 & Equ. 2 & Equ. 3 & Equ. 4 & Equ. 5 & Equ. 6 \\
\hline Constant & $\begin{array}{l}-0.025^{*} \\
(-1.696)\end{array}$ & $\begin{array}{l}0.020 \\
(1.454)\end{array}$ & $\begin{array}{l}-0.127 \\
(-1.457)\end{array}$ & $\begin{array}{l}-0.035^{* *} \\
(-2.139)\end{array}$ & $\begin{array}{l}-0.040 \\
(-0.547)\end{array}$ & $\begin{array}{c}-0.036^{*} \\
(-1.930)\end{array}$ \\
\hline GDPGR $_{\mathrm{t}-1}$ & $\begin{array}{l}-0.042^{*} \\
(-1.954) \\
\end{array}$ & $\begin{array}{l}-0.123 * * * \\
(-2.759)\end{array}$ & $\begin{array}{l}0.047^{*} \\
(1.857) \\
\end{array}$ & $\begin{array}{l}-0.689 * * * \\
(-2.746)\end{array}$ & $\begin{array}{l}-0.158^{*} \\
(-1.768) \\
\end{array}$ & $\begin{array}{l}-0.211^{* * *} \\
(-2.864)\end{array}$ \\
\hline CAP & $\begin{array}{l}1.075 * * * \\
(19.141)\end{array}$ & $\begin{array}{l}0.597 * * * \\
(3.743)\end{array}$ & $\begin{array}{l}0.078 * * * \\
(3.044)\end{array}$ & $\begin{array}{l}0.044^{*} \\
(1.883)\end{array}$ & $\begin{array}{l}0.101^{*} \\
(1.714)\end{array}$ & $\begin{array}{l}0.019 \\
(0.976)\end{array}$ \\
\hline INF & $\begin{array}{l}-0.047 * * \\
(-2.185)\end{array}$ & $\begin{array}{l}-0.162^{* *} \\
(-1.958)\end{array}$ & $\begin{array}{l}0.016 \\
(0.518)\end{array}$ & $\begin{array}{l}-0.053 * * \\
(-2.047)\end{array}$ & $\begin{array}{l}-0.310^{* * *} \\
(-2.772)\end{array}$ & $\begin{array}{l}0.019 \\
(0.976)\end{array}$ \\
\hline LF & $\begin{array}{l}0.912 * * * \\
(16.204)\end{array}$ & $\begin{array}{l}0.460 * * * \\
(4.224)\end{array}$ & $\begin{array}{l}0.035^{*} \\
(1.743)\end{array}$ & $\begin{array}{l}0.205^{* *} \\
(2.334)\end{array}$ & $\begin{array}{l}0.025 * * \\
(2.348)\end{array}$ & $\begin{array}{l}0.044 * * \\
(2.198)\end{array}$ \\
\hline NSAV & $\begin{array}{l}0.959 * * * \\
(16.212)\end{array}$ & $\begin{array}{l}0.070 * * * \\
(3.551)\end{array}$ & $\begin{array}{l}1.257 * * * \\
(22.104)\end{array}$ & $\begin{array}{l}0.217^{* * * *} \\
(3.944)\end{array}$ & $\begin{array}{l}0.036^{*} \\
(1.678) \\
\end{array}$ & $\begin{array}{l}0.116^{*} \\
(1.701) \\
\end{array}$ \\
\hline CBAGDP & $\begin{array}{l}0.597 * * * \\
(3.743) \\
\end{array}$ & $\begin{array}{l}0.191^{*} \\
(1.751) \\
\end{array}$ & $\begin{array}{l}0.179 * * * \\
(6.211) \\
\end{array}$ & $\begin{array}{l}1.101 * * * \\
(18.695)\end{array}$ & $\begin{array}{l}0.035^{*} \\
(1.743) \\
\end{array}$ & $\begin{array}{l}0.044 * * \\
(2.198) \\
\end{array}$ \\
\hline FDI & $\begin{array}{c}-0.045^{*} \\
(-1.768) \\
\end{array}$ & & & $\begin{array}{l}0.051 * * \\
(2.331) \\
\end{array}$ & & \\
\hline PI & & $\begin{array}{l}-0.090 \text { *** } \\
(-3.200)\end{array}$ & & & $\begin{array}{l}0.044 * \\
(1.883)\end{array}$ & \\
\hline DEBT & & & $\begin{array}{l}-0.282 * * * \\
(-3.157)\end{array}$ & & & $\begin{array}{l}0.046^{*} \\
(1.917)\end{array}$ \\
\hline FDI*CBAGDP & & & & $\begin{array}{l}0.036^{*} \\
(1.678) \\
\end{array}$ & & \\
\hline PI*CBAGDP & & & & & $\begin{array}{l}0.025 * * \\
(2.348)\end{array}$ & \\
\hline DEBT*CBAGDP & & & & & & $\begin{array}{l}0.116 * \\
(1.701) \\
\end{array}$ \\
\hline Sargan test & $\begin{array}{l}10.71 \\
{[0.446]}\end{array}$ & $\begin{array}{l}10.33 \\
{[0.612]}\end{array}$ & $\begin{array}{l}14.41 \\
{[0.413]}\end{array}$ & $\begin{array}{l}13.06 \\
{[0.411]}\end{array}$ & $\begin{array}{l}6.80 \\
{[0.791]}\end{array}$ & $\begin{array}{l}8.24 \\
{[0.702]}\end{array}$ \\
\hline A-B test $1^{\text {st }}$ Order & $\begin{array}{c}-1.88^{*} \\
{[0.079]} \\
\end{array}$ & $\begin{array}{l}-8.01 * * * \\
{[0.001]}\end{array}$ & $\begin{array}{l}-2.95 * * \\
{[0.001]}\end{array}$ & $\begin{array}{c}-2.78^{* *} \\
{[0.004]}\end{array}$ & $\begin{array}{l}-5.16^{* * *} \\
{[0.001]}\end{array}$ & $\begin{array}{c}-1.88^{*} \\
{[0.086]} \\
\end{array}$ \\
\hline A-B test $2^{\text {nd }}$ Order & $\begin{array}{l}-0.99 \\
{[0.341]}\end{array}$ & $\begin{array}{l}-0.85 \\
{[0.412]}\end{array}$ & $\begin{array}{l}-0.67 \\
{[0.552]}\end{array}$ & $\begin{array}{l}-0.96 \\
{[0.361]}\end{array}$ & $\begin{array}{l}-0.98 \\
{[0.392]}\end{array}$ & $\begin{array}{l}-0.89 \\
{[0.390]}\end{array}$ \\
\hline Observations & 304 & 304 & 304 & 304 & 304 & 304 \\
\hline
\end{tabular}

Notes: Dependent variable is real GDP per capita growth rate.

All the variables are taken in differences and lagged one period.

The Sargan Chi-square statistic tests the null hypothesis of no correlation between the instruments and residuals.

The Arellano and Bond (A-B) Z-statistic tests the null hypothesis that the residuals are first order correlated (A-B test $1^{\text {st }}$ Order) and the residuals are not second order correlated (A-B test $2^{\text {nd }}$ Order)

The figures in the parentheses are Z-statistic, while in the brackets are probability values (or p-value).

$*, * *$ and $* * *$ The coefficient is significant at $10 \%, 5 \%$ and $1 \%$ levels, respectively. 
The significant and positive association between the financial development and the development of the real economy is consistent with the empirical studies such as Roubini and Sala-i-Martin (1992), King and Levine (1993), Benhabib and Spiegel (2000), and Beck et al. (2000b).

Looking at the impact of the private capital flows, the signs of private capital flow variables are negative and significant in all equations when the interaction term is not included. The results demonstrate that foreign debt may hurt the low-income countries than help to promote their economic performance, as the estimated coefficient is the highest as compared to other capital flows. The negative effect of these capital flows is in line with the results previously estimated by Reisen and Soto (2001) and Levine (2001).

Interestingly, while the estimates for private capital flows are negative (Equations 1-3), the coefficient of national saving are positive, which suggesting that these sorts of capital flows are less productive than national saving, and thus there are less spillover effects from these foreign capitals. This is consistent with the findings reported in firm-level studies by Aitken and Harrison (1999), Haddad and Harrison (1993), Vissak (2009), and Zeng et al. (2009), which indicating that low-income countries have not enough "absorptive capacity" in transferring the advantages embodied in private capital inflows into the positive economic growth.

One possible explanation for these results may be the failure to capture contingency effects in the relationship between private capital flows and economic growth and the relationship between private capital flows and growth may be contingent on other countries' absorptive capabilities such as domestic financial systems and laws and institutional reforms (Brock and Urbonavicius 2008). To determine the validity of the hypothesis that well-developed domestic financial system would help to benefit more from private capital flows, the interaction term is included. From Equations 4 to 6 in Table 3, it is found that the coefficients of the private capital flows and the interaction term are positive and statistically significant in all regressions at 10 percent significance level or better. The positive sign of the interaction term does support the notion that domestic financial system is effectively transforming the negative effect of all private capital flows on growth into positive impact in low-income countries. It is concluded that the effect of private capital flows on growth is greatly influenced through the domestic financial system.

In checking the validity of the instruments used, both Sargan and Arellano-Bond test statistics show that the instruments used are no-overidentifying restrictions and the residuals are independent or white noise, and hence, suitable for the estimations ${ }^{6}$.

\subsection{Further analysis of the relationship between private capital flows, financial development and economic growth}

The relationship between private capital flows, financial development and economic growth may be further investigated by using alternative indicators of financial development. Two alternative measures of financial development are used to gauge different

\footnotetext{
${ }^{6}$ See Newey and McFadden (1994: 2231) for details on this test.
} 
functions of financial intermediary in the system, namely: deposit money bank assets to GDP ratio (DBAGDP) and private credit by deposit money bank to GDP ratio (PCGDP). The first indicator measures the degree of monetization and the relative significance of particular financial institutions. The second indicator takes into account the credits to private sector only and isolates the credits channeled to public sector and credits from central bank.

The results among private capital flows, two financial development measures and growth are reported in Tables 4 and 5. The results reveal that FDI is statistically significant at 10 percent significance level or better and it has a positive impact on growth, either included or excluded the interaction term. Moreover, the coefficient of the interaction term is positive and significant. Hence, it is obvious that FDI flows have an unambiguously positive effect on growth in the low-income countries, which is in line with Amdam et al. (2007), and Basti and Bayyurt (2008).

Looking at both portfolio investment and foreign debt (without interaction term) as reported in Tables 4 and 5, it is noted that these capital flows are negatively associated with economic growth. However, the variable flows are positive and significant after the inclusion of interaction term. This implies an interesting situation that although portfolio investment and foreign debt are negatively associated with economic growth, the well-developed financial system would change this negative impact to positive impact on growth. This finding is consistent with the results reported in Table 3. Again, this provides additional evidence to support the notion that the negative impact of private capital flows can be transferred into positive if the domestic financial system has reached a certain minimum level of development.

Table 4. Private Capital Flows, Financial Development (PCGDP) and Economic Growth in Low-Income Countries, 1988-2006

\begin{tabular}{|c|c|c|c|c|c|c|}
\hline Variable & Equ. 1 & Equ. 2 & Equ. 3 & Equ. 4 & Equ. 5 & Equ. 6 \\
\hline Constant & $\begin{array}{l}-0.014 \\
(-0.626)\end{array}$ & $\begin{array}{l}-0.083 \\
(-0.140)\end{array}$ & $\begin{array}{l}0.023 \\
(0.032)\end{array}$ & $\begin{array}{l}0.130^{* *} \\
(2.054)\end{array}$ & $\begin{array}{l}-0.127 * * * \\
(-2.864)\end{array}$ & $\begin{array}{l}-0.105 \\
(-0.264)\end{array}$ \\
\hline GDPGR $_{\mathrm{t}-1}$ & $\begin{array}{l}0.048^{* *} \\
(2.415)\end{array}$ & $\begin{array}{l}-0.003 \\
(-0.140)\end{array}$ & $\begin{array}{l}0.041 \\
(0.579)\end{array}$ & $\begin{array}{l}-0.407^{* * *} \\
(-4.715)\end{array}$ & $\begin{array}{l}-0.087 * * * \\
(-2.842)\end{array}$ & $\begin{array}{l}0.118^{* *} \\
(2.107)\end{array}$ \\
\hline CAP & $\begin{array}{l}0.045^{*} \\
(1.884)\end{array}$ & $\begin{array}{l}0.103 * \\
(1.786)\end{array}$ & $\begin{array}{l}0.115^{*} \\
(1.748)\end{array}$ & $\begin{array}{l}0.120 \\
(1.402)\end{array}$ & $\begin{array}{l}0.100^{* *} \\
(2.443)\end{array}$ & $\begin{array}{l}0.117^{* *} \\
(2.050)\end{array}$ \\
\hline INF & $\begin{array}{l}-0.163^{*} \\
(-1.801)\end{array}$ & $\begin{array}{l}-0.005 \\
(-0.264)\end{array}$ & $\begin{array}{l}-0.051 * * \\
(-2.331)\end{array}$ & $\begin{array}{l}-0.127 * * * \\
(-2.864)\end{array}$ & $\begin{array}{l}0.014 \\
(0.860)\end{array}$ & $\begin{array}{c}-0.046^{*} \\
(-1.917)\end{array}$ \\
\hline LF & $\begin{array}{l}0.035^{*} \\
(1.758)\end{array}$ & $\begin{array}{l}0.037^{*} \\
(1.726)\end{array}$ & $\begin{array}{l}0.032 * * * \\
(3.081)\end{array}$ & $\begin{array}{l}0.094^{* *} \\
(2.308)\end{array}$ & $\begin{array}{l}0.117 * \\
(1.801)\end{array}$ & $\begin{array}{l}0.011 \\
(0.158)\end{array}$ \\
\hline NSAV & $\begin{array}{l}0.055 * * * \\
(2.772)\end{array}$ & $\begin{array}{l}0.051 * * \\
(2.302)\end{array}$ & $\begin{array}{l}0.028 * * \\
(2.556)\end{array}$ & $\begin{array}{l}0.051 * * \\
(2.569)\end{array}$ & $\begin{array}{l}0.072 * \\
(1.689)\end{array}$ & $\begin{array}{l}0.026^{*} \\
(1.832)\end{array}$ \\
\hline PCGDP & $\begin{array}{l}0.047 * * \\
(2.329)\end{array}$ & $\begin{array}{l}0.045^{*} \\
(1.924)\end{array}$ & $\begin{array}{l}0.008^{* *} \\
(2.201)\end{array}$ & $\begin{array}{l}0.046^{* *} \\
(2.308)\end{array}$ & $\begin{array}{l}0.014^{*} \\
(1.951)\end{array}$ & $\begin{array}{l}0.015^{* *} \\
(1.980)\end{array}$ \\
\hline FDI & $\begin{array}{l}0.117 * \\
(1.713)\end{array}$ & & & $\begin{array}{l}0.166 * * \\
(2.452)\end{array}$ & & \\
\hline
\end{tabular}


End of Table 4

\begin{tabular}{|c|c|c|c|c|c|c|}
\hline Variable & Equ. 1 & Equ. 2 & Equ. 3 & Equ. 4 & Equ. 5 & Equ. 6 \\
\hline PI & & $\begin{array}{l}-0.052 * * * \\
(-2.639)\end{array}$ & & & $\begin{array}{l}0.062 * * * \\
(3.308)\end{array}$ & \\
\hline DEBT & & & $\begin{array}{l}-0.052 * * * \\
(-2.639)\end{array}$ & & & $\begin{array}{l}0.088 * * * \\
(4.362)\end{array}$ \\
\hline FDI* PCGDP & & & & $\begin{array}{l}0.100 * * \\
(2.461)\end{array}$ & & \\
\hline PI* PCGDP & & & & & $\begin{array}{l}0.052 * * * \\
(2.621)\end{array}$ & \\
\hline $\begin{array}{l}\text { DEBT* } \\
\text { PCGDP }\end{array}$ & & & & & & $\begin{array}{l}0.050^{* *} \\
(2.501)\end{array}$ \\
\hline Sargan test & $\begin{array}{l}12.26 \\
{[0.962]}\end{array}$ & $\begin{array}{l}17.12 \\
{[0.837]}\end{array}$ & $\begin{array}{l}17.93 \\
{[0.813]}\end{array}$ & $\begin{array}{l}19.73 \\
{[0.725]}\end{array}$ & $\begin{array}{l}16.41 \\
{[0.852]}\end{array}$ & $\begin{array}{l}14.10 \\
{[0.931]}\end{array}$ \\
\hline $\begin{array}{l}\text { A-B test } 1^{\text {st }} \\
\text { Order }\end{array}$ & $\begin{array}{l}-1.99 * \\
{[0.045]}\end{array}$ & $\begin{array}{l}-1.83 * \\
{[0.075]}\end{array}$ & $\begin{array}{l}-2.98 * * \\
{[0.008]}\end{array}$ & $\begin{array}{l}-1.74 * \\
{[0.082]}\end{array}$ & $\begin{array}{l}-2.37 * * \\
{[0.036]}\end{array}$ & $\begin{array}{l}-2.46^{*} \\
{[0.031]}\end{array}$ \\
\hline $\begin{array}{l}\text { A-B test } 2^{\text {nd }} \\
\text { Order }\end{array}$ & $\begin{array}{l}-0.89 \\
{[0.365]}\end{array}$ & $\begin{array}{l}-0.99 \\
{[0.342]}\end{array}$ & $\begin{array}{l}-0.62 \\
{[0.470]}\end{array}$ & $\begin{array}{l}-0.76 \\
{[0.422]}\end{array}$ & $\begin{array}{l}-0.93 \\
{[0.301]}\end{array}$ & $\begin{array}{l}-0.66 \\
{[0.468]}\end{array}$ \\
\hline Observations & 304 & 304 & 304 & 304 & 304 & 304 \\
\hline
\end{tabular}

Note: Refer to Table 3.

Table 5. Private Capital Flows, Financial Development (DBAGDP) and Economic Growth in Low-Income Countries, 1988-2006

\begin{tabular}{|c|c|c|c|c|c|c|}
\hline Variable & Equ. 1 & Equ. 2 & Equ. 3 & Equ. 4 & Equ. 5 & Equ. 6 \\
\hline Constant & $\begin{array}{l}3.632 * * \\
(2.662)\end{array}$ & $\begin{array}{l}0.029 \\
(0.411)\end{array}$ & $\begin{array}{l}-0.044 * * * \\
(-3.030)\end{array}$ & $\begin{array}{l}-0.080 \\
(-0.067)\end{array}$ & $\begin{array}{l}-0.069 * * * \\
(-3.237)\end{array}$ & $\begin{array}{l}3.926^{* *} \\
(2.700)\end{array}$ \\
\hline GDPGR $_{\mathrm{t}-1}$ & $\begin{array}{l}0.015 * * \\
(2.061) \\
\end{array}$ & $\begin{array}{l}0.036 \\
(0.825) \\
\end{array}$ & $\begin{array}{l}-0.027 \\
(-1.495) \\
\end{array}$ & $\begin{array}{c}-0.107^{*} \\
(-1.719) \\
\end{array}$ & $\begin{array}{l}0.065 \\
(0.068) \\
\end{array}$ & $\begin{array}{l}-0.263 * * * \\
(-4.262)\end{array}$ \\
\hline CAP & $\begin{array}{l}0.172^{* * *} \\
(4.333)\end{array}$ & $\begin{array}{l}0.037 * * * \\
(2.644)\end{array}$ & $\begin{array}{l}1.117^{* * * *} \\
(21.080)\end{array}$ & $\begin{array}{l}2.216^{*} \\
(1.964) \\
\end{array}$ & $\begin{array}{l}0.021^{* * *} \\
(2.865)\end{array}$ & $\begin{array}{l}0.030^{*} \\
(1.672)\end{array}$ \\
\hline INF & $\begin{array}{l}-0.118^{* *} \\
(-2.167)\end{array}$ & $\begin{array}{l}-0.051 * * * \\
(-2.644)\end{array}$ & $\begin{array}{l}-0.061 \\
(-0.043)\end{array}$ & $\begin{array}{c}-0.072 * \\
(-1.759) \\
\end{array}$ & $\begin{array}{l}-3.568 * * * \\
(-2.877)\end{array}$ & $\begin{array}{l}-1.508 \\
(-1.278) \\
\end{array}$ \\
\hline LF & $\begin{array}{l}0.101^{*} \\
(1.850)\end{array}$ & $\begin{array}{l}0.029 \\
(1.320)\end{array}$ & $\begin{array}{l}0.108 * * * \\
(2.698)\end{array}$ & $\begin{array}{l}1.647^{* *} \\
(2.293)\end{array}$ & $\begin{array}{l}0.109 \\
(1.531)\end{array}$ & $\begin{array}{l}0.032 * * * \\
(3.012)\end{array}$ \\
\hline NSAV & $\begin{array}{l}0.033 * * \\
(2.307)\end{array}$ & $\begin{array}{l}0.194 * * * \\
(3.474)\end{array}$ & $\begin{array}{l}0.053 * * * \\
(2.618)\end{array}$ & $\begin{array}{l}0.048 * * \\
(2.302)\end{array}$ & $\begin{array}{l}0.023 * * \\
(2.281)\end{array}$ & $\begin{array}{l}0.057 * * * \\
(2.743)\end{array}$ \\
\hline DBAGDP & $\begin{array}{l}0.132 * * \\
(3.155)\end{array}$ & $\begin{array}{l}0.086^{* *} \\
(2.176)\end{array}$ & $\begin{array}{l}0.454^{*} \\
(1.886)\end{array}$ & $\begin{array}{l}2.771^{* *} \\
(2.126)\end{array}$ & $\begin{array}{l}0.792 * \\
(1.918)\end{array}$ & $\begin{array}{l}2.321^{*} \\
(1.780)\end{array}$ \\
\hline FDI & $\begin{array}{l}0.026^{*} \\
(1.816)\end{array}$ & & & $\begin{array}{l}0.085^{* *} \\
(2.379)\end{array}$ & & \\
\hline PI & & $\begin{array}{l}-0.052 * * * \\
(-2.639)\end{array}$ & & & $\begin{array}{l}0.090 * * \\
(2.255)\end{array}$ & \\
\hline
\end{tabular}


End of Table 5

\begin{tabular}{|c|c|c|c|c|c|c|}
\hline Variable & Equ. 1 & Equ. 2 & Equ. 3 & Equ. 4 & Equ. 5 & Equ. 6 \\
\hline DEBT & & & $\begin{array}{l}-0.133^{* *} \\
(-2.408)\end{array}$ & & & $\begin{array}{l}0.052 * * * \\
(2.649)\end{array}$ \\
\hline FDI* DBAGDP & & & & $\begin{array}{l}0.065^{* *} \\
(2.415)\end{array}$ & & \\
\hline PI* DBAGDP & & & & & $\begin{array}{l}0.047 * * * \\
(3.108)\end{array}$ & \\
\hline DEBT* DBAGDP & & & & & & $\begin{array}{l}0.131 * * * \\
(2.879)\end{array}$ \\
\hline Sargan test & $\begin{array}{l}12.23 \\
{[0.851]}\end{array}$ & $\begin{array}{l}17.61 \\
{[0.862]}\end{array}$ & $\begin{array}{l}16.88 \\
{[0.889]}\end{array}$ & $\begin{array}{l}13.36 \\
{[0.841]}\end{array}$ & $\begin{array}{l}19.69 \\
{[0.622]}\end{array}$ & $\begin{array}{l}15.46 \\
{[0.776]}\end{array}$ \\
\hline A-B test $1^{\text {st }}$ Order & $\begin{array}{l}-1.93^{*} \\
{[0.052]}\end{array}$ & $\begin{array}{l}-2.96 * * * \\
{[0.004]}\end{array}$ & $\begin{array}{l}-2.26^{* *} \\
{[0.021]}\end{array}$ & $\begin{array}{l}-2.39 * * \\
{[0.023]}\end{array}$ & $\begin{array}{l}-1.76^{*} \\
{[0.077]}\end{array}$ & $\begin{array}{l}-2.19 * * \\
{[0.025]}\end{array}$ \\
\hline A-B test $2^{\text {nd }}$ Order & $\begin{array}{l}-0.88 \\
{[0.362]}\end{array}$ & $\begin{array}{l}-0.91 \\
{[0.323]}\end{array}$ & $\begin{array}{l}-0.89 \\
{[0.376]}\end{array}$ & $\begin{array}{l}-0.99 \\
{[0.331]}\end{array}$ & $\begin{array}{l}-0.93 \\
{[0.321]}\end{array}$ & $\begin{array}{l}-0.83 \\
{[0.411]}\end{array}$ \\
\hline Observations & 304 & 304 & 304 & 304 & 304 & 304 \\
\hline
\end{tabular}

Note: Refer to Table 3.

\section{Conclusions and policy implications}

In this paper, we have investigated the effect of different sorts of private capital flows (FDI, portfolio investment and foreign debt) on economic growth in the selected lowincome countries for the period of 1988-2006. We found that FDI has a positive effect on economic growth in the low-income countries while portfolio investment and total foreign debt have negative and significant impacts on economic growth. Our interpretation for the negative sign for these private capital flows is that low degree of the financial sector development in the low-income countries leads to misallocation of these private capital flows, which reduces and even reverses their impacts on economic performance. Hence, well-developed financial system is of importance and the transition of the local financial market is a must in dealing with the presence of private capital flows.

To support this idea, we allowed interaction of all private capital flows (FDI, foreign debt and portfolio investment) with different measures of financial sector development. When these private capital flows were interacted with financial development indicators, even though the sign of both portfolio investment and foreign debt remain negative and significant in the regressions, the interaction terms are generally positive and significant, which implies the importance of financial sector development in benefiting from private capital flows. Our findings are different from the previous findings. Arteta et al. (2001), for example, do not find any significant linkages among financial opening, level of financial depth and income level in a panel of countries. On the other hand, Klein and Olivei (1999) also reveal that the presence of private capital flows only significant in OECD countries only, but not for developing countries. Similarly, Edwards (2001) shows that financial liberalisation had a positive effect on growth only in more developed countries, supporting the hypothesis of the role of well-functioning financial 
institutions. Our findings show that making private capital flows more systematically conditional on the development of domestic financial sector would tend to increase its impact on growth. This explains why the impact of private capital flows on growth is not all the time positive.

A crucial starting point in designing policies to optimize the benefits from private capital flows is to have a basic understanding of a country's comparative advantage and development objectives. This helps in absorbing the benefits embodied in private capital flows effectively (United Nations Conference on Trade and Development 2002). Even though it is important for low-income developing countries to attract more foreign private capital flows, they should be careful in dealing with the presence of these capital inflows since the nature of these private capital flows are quite different. It is recommended that low-income countries, or emerging economies give priority to foreign direct investment (FDI) as this is the most preferred capital flow contributing to the economic growth.

\section{Acknowledgements}

This paper is a product of an on-going research (entitled: Foreign Direct Investment, Economic Growth and Institutional Innovations: The Cross-National Evidence (FRGS/1/10/SSK/UTAR/03/2)) sponsored by Fundamental Research Grant Scheme (FRGS), Ministry of Higher Education (MOHE), Malaysia. Views expressed in this paper are not necessarily those of MOHE, Malaysia.

\section{References}

Adams, S. 2009. Foreign direct investment, domestic investment, and economic growth in SubSaharan Africa, Journal of Policy Modeling 31: 939-949. doi:10.1016/j.jpolmod.2009.03.003

Aitken, B. J.; Harrison, A. E. 1999. Do domestic firms benefit from direct foreign investment? Evidence from Venezuela, American Economic Review 89(3): 605-618. doi:10.1257/aer.89.3.605

Albuquerque, R. 2003. The composition of international capital flows: risk sharing through foreign direct investment, Journal of International Economics 61(2): 353-383.

doi:10.1016/S0022-1996(03)00013-8

Alfaro, L.; Chanda, A.; Sebnem, K. O.; Sayek, S. 2004. FDI and economic growth: the role of local financial markets, Journal of International Economics 64(1): 89-112.

doi:10.1016/S0022-1996(03)00081-3

Amdam, R. P.; Lunnan, R.; Ramanauskas, G. 2007. FDI and the transformation from industry to service society in emerging economies: A Lithuanian-Nordic perspective, Inzinerine Ekonomika Engineering Economics (1): 22-28.

Andersen, T. B.; Tarp, F. 2003. Financial liberalization, financial development and economic growth in LDCs, Journal of International Development 15(2): 189-209. doi:10.1002/jid.971

Arellano, M.; Bond, S. 1991. Some tests of specification for panel data: Monte Carlo evidence and an application to employment equations, Review of Economic Studies 58(2): 277-297. doi: $10.2307 / 2297968$

Arellano, M.; Bover, O. 1995. Another look at the instrumental variable estimation of errorcomponent models, Journal of Econometrics 68: 29-51. doi:10.1016/0304-4076(94)01642-D

Arteta, C.; Eichengreen, B.; Wyplosz, C. 2001. When does capital account liberalization help more than it hurts? NBER Working Paper 8414. 
Azman-Saini, W. N. W.; Law, S. H.; Ahmad, A. H. 2010. FDI and economic growth: new evidence on the role of financial markets, Economics Letters 107: 211-213.

doi:10.1016/j.econlet.2010.01.027

Baharumshah, A. Z.; Thanoon, M. A. M. 2006. Foreign capital flows and economic growth in East Asian countries, China Economic Review 17(1): 70-83. doi:10.1016/j.chieco.2005.09.001

Balasubramanyam, V. N.; Salisu, M.; Sapsford, D. 1996. Foreign direct investment and growth in EP and IS countries, Economic Journal 106(1): 92-105. doi:10.2307/2234933

Basti, E.; Bayyurt, N. 2008. Efficiency performance of foreign-owned firms in Turkey, Transformations in Business and Economics 7(3): 20-30.

Beck, T.; Demirgüç-Kunt, A.; Levine, R. 2000a. A New Database on the Structure and Development of the Financial Sector, World Bank Economic Review 14: 597-605. doi:10.1093/ wber/14.3.597

Beck, T.; Levine, R.; Loyaza, N. 2000b. Finance and the sources of growth, Journal of Financial Economics 58(1-2): 261-300. doi:10.1016/S0304-405X(00)00072-6

Benhabib, J.; Spiegel, M. M. 2000. The role of financial development in growth and investment, Journal of Economic Growth 5(4): 341-360. doi:10.1023/A:1026599402490

Blejer, M. I. 2006. Economic growth and the stability and efficiency of the financial sector, Journal of Banking and Finance 30(12): 3429-3432. doi:10.1016/j.jbankfin.2006.06.001

Blundell, R.; Bond, S. 1998. Initial conditions and moment restrictions in dynamic panel data models, Journal of Econometrics 87(1): 115-143. doi:10.1016/S0304-4076(98)00009-8

Bordo, M. D.; Meissner, C. M. 2006. The role of foreign currency debt in financial crises: 1880-1913 versus 1972-1997, Journal of Banking and Finance 30(12): 3299-3329. doi:10.1016/j.jbankfin.2006.05.013

Borensztein, E.; De Gregorio, J.; Lee, J. W. 1998. How does foreign direct investment affect economic growth? Journal of International Economics 45: 115-135.

doi:10.1016/S0022-1996(97)00033-0

Brock, G.; Urbonavicius, S. 2008. Regional FDI growth in Lithuania, 1996-2003, Transformations in Business and Economics 7(1): 80-88.

de Mello, L. R. 1996. Foreign direct investment, international knowledge transfers, endogenous growth: time series evidence. Department of Economics, University of Kent, United Kingdom.

de Mello, L. R. 1997. Foreign direct investment in developing countries and growth: a selective survey, The Journal of Development Studies 34(1): 1-34. doi:10.1080/00220389708422501

Dumludag, D. 2009. An analysis of the determinants of foreign direct investment in turkey: the role of the institutional context, Journal of Business Economics and Management 10(1): 15-30. doi:10.3846/1611-1699.2009.10.15-30

Durham, J. B. 2004. Absorptive capacity and the effects of foreign direct investment and equity foreign portfolio investment on economic growth, European Economic Review 48(2): 285-306. doi:10.1016/S0014-2921(02)00264-7

Edwards, S. 1991. Capital flows, foreign direct investment and debt-equity swaps in developing countries, in H. Siebert (Ed.). Capital Flows in the World Economy. Moha, Tubingen, 255-281.

Eller, M.; Haiss, P.; Steiner, K. 2006. Foreign direct investment in the financial sector and economic growth in Central and Eastern Europe: the crucial role of the efficiency channel, Emerging Markets Review 7(4): 300-319. doi:10.1016/j.ememar.2006.09.001

Errunza, W. 2001. Foreign portfolio equity investments, financial liberalization, and economic development, Review of International Economics 9: 703-726. doi:10.1111/1467-9396.00308

Giovanni, J. 2005. What drives capital flows? The case of cross-border M\&A activity and financial deepening, Journal of International Economics 65(1): 127-149.

doi:10.1016/j.jinteco.2003.11.007 
Haddad, M.; Harrison, A. 1993. Are there positive spillovers from direct foreign investment? Evidence from panel data for Morocco, Journal of Development Economics 42(1): 51-74. doi:10.1016/0304-3878(93)90072-U

Hermes, N.; Lensink, R. 2003. Foreign direct investment, financial development and economic growth, Journal of Development Studies 40(1): 142-163. doi:10.1080/00220380412331293707

Khamfula, Y. 2007. Foreign direct investment and economic growth in EP and IS countries: the role of corruption, The World Economy 30(12): 1843-1854. doi:10.1111/j.1467-9701.2007.01055.x

King, R. G.; Levine, R. 1993. Finance and growth: Schumpeter might be right, Quarterly Journal of Economics 108(3): 717-737. doi:10.2307/2118406

Klein, M.; Olivei, G. 1999. Capital account liberalization, financial depth and economic growth. NBER Working Paper 7384.

Levine, R. 1997. Financial development and economic growth: views and agenda, Journal of Economic Literature 35(2): 688-726.

Levine, R. 2001. International financial liberalization and economic growth, Review of International Economics 9(4): 688-702. doi:10.1111/1467-9396.00307

Liu, X.; Shu, C.; Sinclair, P. 2009. Trade, foreign direct investment and economic growth in Asian economies, Applied Economics 41(13): 1603-1612. doi:10.1080/00036840701579176

Mody, A.; Murshid, A. P. 2005. Growing up with capital flows, Journal of International Economics 65(1): 249-266. doi:10.1016/j.jinteco.2004.02.003

Newey, W.; McFadden, D. 1994. Large sample estimation and hypothesis testing, in R. Engle, D. McFadden. Handbook of Econometrics. North-Holland, Amsterdam, 4: 2111-2245.

Pazienza, P.; Vecchione, V. 2009. Preliminary investigation of the determinants of FDI distribution in Italy, Journal of Business Economics and Management 10(2): 99-107.

doi:10.3846/1611-1699.2009.10.99-107

Reisen, H.; Soto, M. 2001. Which types of capital inflows foster developing-country growth? International Finance 4(1): 1-14. doi:10.1111/1468-2362.00063

Rodrik, D.; Velasco, A. 1999. Short-term capital flows. NBER Working Paper 7364.

Roubini, N.; Sala-i-Martin, X. 1992. Financial repression and economic growth, Journal of Development Economics 39(1): 5-30. doi:10.1016/0304-3878(92)90055-E

Soto, M. 2003. Taxing capital flows: an empirical comparative analysis, Journal of Development Economics 72: 203-221. doi:10.1016/S0304-3878(03)00074-9

Tvaronavičienè, M.; Grybaite, V.; Korsakienė, R. 2008. Foreign capital destinations: Baltic States versus India, Journal of Business Economics and Management 9(3): 227-234.

doi:10.3846/1611-1699.2008.9.227-234

Tvaronavičienè, M.; Kalašinskaite, K. 2010. Whether globalization in form of FDI enhances national wealth: empirical evidence from Lithuania, Journal of Business Economics and Management 11(1): 5-19. doi:10.3846/jbem.2010.01

Ucal, M.; Özcan, K. M.; Bilgin, M. H.; Mungo, J. 2010. Relationship between financial crisis and foreign direct investment in developing countries using semiparametric regression approach, Journal of Business Economics and Management 11(1): 20-33. doi:10.3846/jbem.2010.02

United Nations Conference on Trade and Development (UNCTAD) 2002. World Investment Report 2002: Transnational Corporations and Export Competitiveness. United Nations, New York and Geneva.

Vissak, T. 2009. The Impact of FDI on Host Country Subsidiaries: Three Case-Stories from Estonia, Transformations in Business and Economics 8(1): 34-49. 
Wachtel, P. 2003. How much do we really know about growth and finance? Federal Reserve Bank of Atlanta, Economic Review (Q1): 33-47.

Wang, M.; Wong, M. C. S. 2009. Foreign direct investment and economic growth: the growth accounting perspectives, Economic Enquiry 47: 701-710. doi:10.1111/j.1465-7295.2008.00133.x

Weng, Y.; Yang, C. H.; Tu, F. C. 2010. Outward foreign direct investment and product quality of domestic productions: an empirical investigation, Journal of Business Economics and Management 11(3): 396-414. doi:10.3846/jbem.2010.19

Zeng, S. X., Wan, T. W.; Tam, V. W. Y. 2009. Towards FDI and Technology Spillover: A Case Study in China, Transformations in Business and Economics 8(1): 50-62.

\title{
PRIVATAUS KAPITALO SRAUTŲ ITAKA MAŽAS PAJAMAS GAUNANČIOMS ŠALIMS: FINANSINIO VIDAUS SEKTORIAUS VAIDMUO
}

\author{
C.-K. Choong, S.-Y. Lam, Z. Yusop
}

\section{Santrauka}

Ryšys tarp kapitalo srautų ir jų augimo yra intensyviai tiriamas. Pastebėta, kad daug prieštaravimų tarp jų vis dar išlieka. Šiame tyrime nagrinejjamas santykis tarp privataus kapitalo srautų (įeinančių užsienio investiciju, portfelinių investicijų ir užsienio skolų) finansinès plètros ir ekonominès veiklos pasirinktose šešiolikoje mažas pajamas gaunančiu besivystančiu šalių 1988-2006 m., duomenų analizei taikant apibendrinamajį momentų metodą (GMM). Nustatyta kad privataus kapitalo srautai turi teigiamą itaką augimui mažas pajamas turinčiose šalyse su gerai išplètotu finansiniu sektoriumi, tačiau daro neigiamą poveiki toms šalims, kurių finansinis sektorius yra skurdus. Gerai išvystyti ekonominiai sektoriai yra tie, kurie vaidina lemiamą vaidmeni ekonominiam augimui. Rezultatai parodè, kad privataus kapitalo srautai būtų efektyvesni, jei jie sistemiškiau priklausytų nuo gerai išsivysčiusių finansinių sistemų.

Reikšminiai žodžiai: privataus kapitalo srautai, akcijų rinka, augimas, duomenų analizè.

Chee-Keong CHOONG. An Assistant Professor and deputy dean at Faculty of Business and Finance, Universiti Tunku Abdul Rahman, Malaysia. He completed his doctorate degree at the Faculty of Economics and Management, Universiti Putra Malaysia (UPM), Malaysia in 2007. He teaches Economics, Business Finance, Statistics for Economics and Management, Basic Econometrics, Econometrics, Research Methods and Business Research Methodology. He has published widely in various refereed journals, which include Energy Policy, Japan and the World Economy, Singapore Economic Review, Pacific Economic Bulletin, African Journal of Business Management, and Journal of the Asia Pacific Economy. His current research interests are in the fields of applied macroeconomics, international economics, monetary economics and financial economics.

Siew-Yong LAM. A lecturer from Faculty of Business and Finance, Universiti Tunku Abdul Rahman (UTAR), Malaysia. She has published a number of journals such as Global Economic Review, ICFAI Journal of Managerial Economics, Icfai Journal of Service Marketing and Banker's Journal Malaysia. Her research interests are in the areas of Relationship Marketing, Consumer Behaviour and managerial economics.

Zulkornain YUSOP. An Associate Professor and deputy dean at Faculty of Economics and Management, Universiti Putra Malaysia. He teaches International Economics, International Trade and Current Issues in International Economics. Topics for research include FDI, private capital flow, capital flight and Economic Integration. He has published a number of journals such as International Journal of Business and Society, Journal of International Food and Agribusiness Marketing, World Review of Entrepreneurship, Management and Sustainable Development, The Singapore Economic Review, The ICFAI Journals, ASEAN Economic Bulletin, Journal of the Asia Pacific Economy and Applied Economics Letters. 